\title{
RESEARCH
}

Open Access

\section{Catastrophic healthcare expenditure and impoverishment in tropical deltas: evidence from the Mekong Delta region}

\author{
Sayem Ahmed ${ }^{1,2^{*}}$ (D), Sylvia Szabo ${ }^{3,4}$ and Kristine Nilsen ${ }^{5,6}$
}

\begin{abstract}
Background: Universal health coverage implies that people obtain the health services they need without experiencing financial hardship. While the factors contributing to catastrophic health expenditure (CHE) among households are well understood, few studies have examined this relationship in the context of environmentally vulnerable regions, such as tropical deltas. This study aims to examine the disparities in the prevalence of CHE and impoverishment due to out-of-pocket (OOP) healthcare payments in the Mekong Delta in comparison with rest of Vietnam. It also intends to investigate the associations between economic and environmental shocks, CHE and the impoverishment from healthcare payments.
\end{abstract}

Methods: Using data from the Vietnam Household Living Standards Survey 2012, the prevalence of CHE was estimated from the fraction of healthcare costs in relation to household consumption expenditure. The poverty headcount was estimated using the total household consumption expenditure considering both with and without OOP expenditure for healthcare in comparison with the national poverty-line. Simple and multiple logistic regression models were used to examine the associations between geography, health systems, environmental and demographic variables and OOP healthcare expenditure related CHE, and impoverishment respectively.

Results: Both the level of OOP household healthcare expenditure and the proportion of households suffering from impoverishment as the result of such payments were higher in the Mekong Delta region compared to rest of Vietnam. Although the results from the multiple regression analysis showed that households in the Mekong Delta region were significantly less likely to suffer from CHE, they were significantly more likely to be impoverished due to OOP healthcare expenditure. While health insurance membership did not have a significant effect on either outcomes, households that faced an economic or an environmental shock in past 5 years were considerably more likely to suffer from CHE and impoverishment from OOP healthcare payments.

Conclusions: The findings suggest that the financial protection capacity of health insurance schemes in Vietnam should be improved and expanded to reduce impoverishment as the result of OOP healthcare payments, particularly in the Mekong Delta region. Additional investments in disaster preparedness strategies can further help to reduce the financial burden of households in this environmentally vulnerable region.

Keywords: Out-of-pocket payments, Catastrophic health expenditure, Universal health coverage, Mekong Delta, Vietnam

\footnotetext{
* Correspondence: sayemahmed@icddrb.org

${ }^{1}$ Health Economics and Financing Research Group, Health Systems and Population Studies Division, International Centre for Diarrhoeal Disease Research, Bangladesh (icddr,b), 68 Shahid Tajuddin Ahmed Sharani, Mohakhali, Dhaka 1212, Bangladesh

${ }^{2}$ Department of Learning, Informatics, Management and Ethics (LIME),

Karolinska Institutet, Stockholm, Sweden

Full list of author information is available at the end of the article
}

(c) The Author(s). 2018 Open Access This article is distributed under the terms of the Creative Commons Attribution 4.0 International License (http://creativecommons.org/licenses/by/4.0/), which permits unrestricted use, distribution, and reproduction in any medium, provided you give appropriate credit to the original author(s) and the source, provide a link to the Creative Commons license, and indicate if changes were made. The Creative Commons Public Domain Dedication waiver (http://creativecommons.org/publicdomain/zero/1.0/) applies to the data made available in this article, unless otherwise stated. 


\section{Background}

Globally, delta regions are home to more than half a billion people and are economically important because of their relatively high agricultural production, rich biodiversity and ecosystems [1, 2]. As most tropical delta regions are located in low and middle-income countries and are prone to environmental and climate change, delta populations often suffer from multiple socioeconomic and environmental vulnerabilities [3, 4]. While there is a growing literature describing the interlinkages between environmental factors and population dynamics [5-7], the research on environmental factors and health and healthcare including health expenditure in delta regions is limited. Despite varying socio-economic development of tropical deltas, people in these low-lying areas face particular health challenges resulting, amongst others, from the effects of natural hazards and creeping processes, such as soil salinization [4]. Because of relatively high population densities in these regions, environmental disasters and natural hazards are likely to affect large populations, who are often poor and have limited physical and financial access to health facilities.

In the Mekong Delta region, more specifically, the negative health effects of floods include water-borne diseases (e.g. diarrhoea), mosquito-borne diseases (e.g. malaria) and infections resulting from the contact with contaminated water $[8,9]$. These health risks are, in turn, often translated into increasing out-of-pocket (OOP) expenditure on health, thus contributing to a households' poverty and jeopardizing individual wellbeing $[10,11]$. Expenditure on healthcare can have important effects on poverty at both micro and macro levels. At the country level, it can have a negative impact on the national poverty estimates, while at the individual level, it exacerbates household poverty, especially for those belonging to the lowest wealth quintile. Recent research from Kenya found that at the household level, 1. 48 million Kenyans were pushed into poverty because of OOP healthcare payments [12]. An analysis of household survey data in Vietnam showed that between 2002 and 2010, OOP healthcare payments in Vietnam increased from US\$ 4.4 to US\$ 12.8. It was also found that $3.4 \%$ and $2.5 \%$ of the population become impoverished in Vietnam due to OOP healthcare payments in 2002 and 2010 respectively [11].

The large and unpredictable OOP healthcare payments can expose households to substantial financial risk and, at their most extreme, may result in impoverishment. Protecting households from such healthcare payments are desirable objectives of every health systems. Therefore, the Sustainable Development Goals (SDG), namely goal 3, include universal health coverage (UHC) as an important agenda objective [13]. The Government of Vietnam adopted a plan for achieving UHC, which aims to expand coverage of current social health insurance to at least $80 \%$ of the population and to reduce OOP healthcare expenditure to less than $40 \%$ of total healthcare spending [14]. Currently, $60 \%$ of the population in Vietnam is covered by social health insurance and households bear $47.6 \%$ of total healthcare expenditure of the country $[14,15]$.

In this context, the objective of this study is to examine the disparities in the prevalence of OOP health expenditure related catastrophic health expenditure (CHE) and impoverishment in the Mekong Delta region in comparison with rest of Vietnam. It also intends to investigate the associations between economic and environmental shocks, CHE and the impoverishment from healthcare payments. By conducting this analysis, this paper contributes to the literature on the determinants of $\mathrm{CHE}$ and impoverishment and the increasingly large body of literature on the socio-economic development of environmentally vulnerable tropical deltas [5-7].

\section{Methods \\ Data and key variables}

We used secondary data from the 2012 Vietnam Household Living Standards Survey (VHLSS). VHLSS are cross-sectional surveys regularly conducted since 1992-93 and representative at national, regional and provincial levels. The 2012 VHLSS represents the 8th round of data collection conducted through face-toface interviews with household heads conducted by the General Statistical Office (GSO) of Vietnam. This survey employed a two-stage stratified cluster design sampling technique with a total sample of 9402 households $[16,17]$. Communes were selected in the first stage and 3 enumeration areas per commune were selected in the second stage [17]. The main variables of interest in this study are the variables measuring the level of monthly consumption expenditure and OOP healthcare payments by each household in the Mekong Delta region vs. rest of Vietnam.

OOP healthcare payments refer to any payments made by households at the point they receive healthcare services (e.g. consultation fees, bed charges, diagnostic cost, medicine cost) and other related non-medical expenses (e.g. transportation cost, tips). The incidence of $\mathrm{CHE}$ was estimated from the fraction of OOP healthcare payments in relation to household consumption expenditure, which exceeds a certain threshold [18]. Two threshold levels were used to estimate the incidence of CHE. These are OOPs exceeding, 10\% of households' total consumption expenditure [19] and 40\% of household' non-subsistence expenditure [20]. The household consumption expenditure comprises both monetary and in-kind payments on all goods and services, and the monetary value of the consumption of home-made 
products [21]. The main explanatory variable in this study was whether the household resides in Mekong region or in another region in Vietnam. The Mekong Delta region was defined based on the administrative classification conducted by the GSO. As control variables, we included adjusted expenditure quintiles, household size, age, gender and educational attainment of the household head [11, 22]. In addition, we controlled for household location (urban vs. rural), health insurance status, if a household member were hospitalised and whether a household suffered from an economic or environmental shock in the last 5 years before the survey. As per the categorization of the GSO, these shocks included: lower incomes, job loss or underemployment, death or sickness of a household member, increased production costs, low selling prices, decreased arable land or water surface and harvest loss related to droughts, floods, and pests. Since two-stage cluster random sampling method was employed for data collection, the analyses accounted for probability sample weight. The difference in OOP healthcare expenditure, the incidence of $\mathrm{CHE}$ and impoverishment between Mekong Delta and rest of Vietnam were tested using independent sample t-test. Chi-square test was performed for testing association of CHE and impoverishment impact of OOP healthcare payments with socio-economic and demographic characteristics of households and other factors. For conversion from Viet Nam Dong (VND) to United States Dollar (USD), we used an exchange rate of 2012 (1 USD = 20,828 VND) [23].

\section{Poverty line and impoverishment}

For measuring the impoverishment effect of OOP healthcare payments, the national poverty line provided by the GSO was used. The poverty headcount was estimated using total household consumption expenditure and such expenditure without OOP payments for healthcare. The gap between these two poverty headcount measurements captured the effect of OOP healthcare payments on poverty. A non-poor household was impoverished by healthcare payments when it becomes poor after paying for health services, based on the poverty line [24].

We used the GSO's poverty line estimates based on the 2012 VHLSS data. The GSO has been using cost-ofbasic-needs approach for calculation of poverty lines since the early 1990s but updated by the GSO and the World Bank following the 2010 VHLSS survey [25]. The revised consumption indices take into consideration the changing consumption patterns of Vietnamese households. The new 2010 poverty line was VND 653,000 (USD 31.4) per individual per month, which is considerably higher than the previously used benchmark [25]. For urban areas, the poverty line was VND 500,000
(USD 24.0) per person per month and for rural areas it was VND 400,000 (USD 19.2) per person per month [26]. Based on these updated thresholds, the poverty headcount was $20.7 \%$ in 2010 and $17.2 \%$ in 2012. The poverty headcount in the Mekong Delta region was slightly lower than the national average, $18.7 \%$ in 2010 and $16.2 \%$ in 2012 [27].

The Pen's Parade graph was drawn to present the impoverishment effect of OOP healthcare payments. In this graph, household consumption was expressed as multiples of a national poverty line and presented in the vertical axis. For each household, the downward vertical bar, or "paint drop," shows the extent to which the subtraction of OOP healthcare payments reduces consumption. If a bar crosses the poverty line, then a household is counted as poor on the basis of reduced consumption due to OOP healthcare payments [18]. We calculated number of individual fell into poverty in association with OOP healthcare expenditure by multiplying total population in 2012 with estimated additional poverty head count related to such payment.

\section{Econometric analysis}

Simple and multiple logistic regression analyses were employed considering $\mathrm{CHE}$ and impoverishment as dependent variables and residence in the Mekong Delta region as the main explanatory variable of interest. The socio-economic characteristics (such as sex and education of household head, household size, expenditure quintiles, geographic location, chronic illness, health insurance status and healthcare seeking from private facilities) were included as control variables in these models. The multiple logistic regression models were specified as:

$$
\begin{aligned}
\operatorname{logit}\left(Y_{i}\right) & =\beta_{0}+\beta_{1} X_{1 i}+\beta_{2} X_{2 i}+\ldots+\varepsilon_{i} \ldots \ldots \ldots(I) \\
i & =1,2 \ldots n
\end{aligned}
$$

In the first two model, Yi denotes incidence of $\mathrm{CHE}$ with a values 0 or $1(0=$ not facing $\mathrm{CHE}, 1=$ facing $\mathrm{CHE})$. In 3rd and 4th model, $\mathrm{Y}_{\mathrm{i}}$ denotes impoverishment from OOP healthcare payments $(0=$ not impoverished from OOP, 1 = impoverished from OOP). For all models, $\beta_{0}$ is a constant and $X_{1 i}$ denotes the residence region variable $(1=$ Mekong region and $0=$ Rest of Vietnam). The $X_{2 i} \ldots$ denote the control variables. The $\beta_{1}, \beta_{2} \ldots$ denote adjacent coefficients to the corresponding independent variables and $\varepsilon_{\mathrm{i}}$ represents an error term.

\section{Results}

\section{Characteristics of respondents}

Table 1 provides information about the characteristics of the households in the Mekong Delta region and rest of Vietnam. While male-headed households were the norm, a higher proportion of households were headed by 
Table 1 Characteristics of the sample

\begin{tabular}{|c|c|c|c|c|c|}
\hline \multirow[t]{2}{*}{ Characteristics } & \multicolumn{2}{|c|}{ Mekong Delta region $(N=1905)$} & \multicolumn{2}{|c|}{ Rest of Vietnam $(N=7494)$} & \multirow[t]{2}{*}{$P$-value } \\
\hline & $\%$ & $(95 \% \mathrm{Cl})$ & $\%$ & $(95 \% \mathrm{Cl})$ & \\
\hline \multicolumn{6}{|c|}{ Sex of the household head } \\
\hline Male & 71.9 & $(69.9-73.9)$ & 76.0 & $(75.1-77.0)$ & \multirow[t]{2}{*}{$0.000^{1)}$} \\
\hline Female & 28.1 & $(26.1-30.1)$ & 24.0 & $(23.0-24.9)$ & \\
\hline \multicolumn{6}{|l|}{ Age of household head } \\
\hline Under 60 years & 74.0 & $(72.0-76.0)$ & 77.6 & $(76.6-78.5)$ & \multirow[t]{2}{*}{$0.001^{1)}$} \\
\hline $60+$ & 26.0 & $(24.0-28.0)$ & 22.4 & $(21.5-23.4)$ & \\
\hline \multicolumn{6}{|c|}{ Ethnicity of household head } \\
\hline Kinh & 91.9 & $(90.6-93.1)$ & 79.8 & (78.9-80.7) & \multirow[t]{2}{*}{$0.000^{1)}$} \\
\hline Other & 8.1 & $(6.9-9.4)$ & 20.2 & $(19.3-21.1)$ & \\
\hline \multicolumn{6}{|c|}{ Education of the household head } \\
\hline Up to primary & 75.2 & $(73.2-77.1)$ & 45.1 & $(44.0-46.2)$ & \multirow[t]{3}{*}{$0.000^{2)}$} \\
\hline Secondary & 21.5 & $(19.7-23.4)$ & 48.1 & $(46.9-49.2)$ & \\
\hline University and others & 3.3 & $(2.5-4.1)$ & 6.8 & $(6.3-7.4)$ & \\
\hline \multicolumn{6}{|l|}{ Household size } \\
\hline $1-2$ persons & 16.6 & $(15.0-18.3)$ & 19.8 & $(18.9-20.7)$ & \multirow[t]{3}{*}{$0.005^{2)}$} \\
\hline $3-4$ persons & 51.4 & $(49.1-53.6)$ & 50.2 & $(49.1-51.3)$ & \\
\hline 5 persons or more & 32.0 & $(29.9-34.1)$ & 30.0 & $(28.9-31.0)$ & \\
\hline \multicolumn{6}{|c|}{ Having elderly people in the household } \\
\hline No & 65.9 & $(63.8-68.1)$ & 69.7 & $(68.6-70.7)$ & \multirow[t]{2}{*}{$0.002^{1)}$} \\
\hline Yes & 34.1 & $(31.9-36.2)$ & 30.3 & $(29.3-31.4)$ & \\
\hline \multicolumn{6}{|c|}{ Having child in the household } \\
\hline No & 35.6 & $(33.5-37.8)$ & 41.8 & $(40.7-42.9)$ & \multirow[t]{2}{*}{$0.000^{1)}$} \\
\hline Yes & 64.4 & $(62.2-66.5)$ & 58.2 & $(57.1-59.3)$ & \\
\hline \multicolumn{6}{|c|}{ Observed economic/environmental shock during past 5 years } \\
\hline No & 73.0 & $(71.0-75.0)$ & 85.6 & $(84.8-86.4)$ & \multirow[t]{2}{*}{$0.000^{1)}$} \\
\hline Yes & 27.0 & $(25.0-29.0)$ & 14.4 & $(13.6-15.2)$ & \\
\hline \multicolumn{6}{|l|}{ Location } \\
\hline Urban & 23.9 & $(22.0-25.9)$ & 30.0 & $(28.9-31.0)$ & \multirow[t]{2}{*}{$0.000^{1)}$} \\
\hline Rural & 76.1 & $(74.1-78.0)$ & 70.0 & $(69.0-71.1)$ & \\
\hline \multicolumn{6}{|c|}{ Household with at least one health insurance enrolee } \\
\hline No & 17.4 & $(15.7-19.1)$ & 10.8 & $(10.1-11.6)$ & $0.000^{1)}$ \\
\hline Yes & 82.6 & $(80.9-84.3)$ & 89.2 & $(88.4-89.9)$ & \\
\hline Hospitalized member & & & & & \\
\hline No & 19.6 & $(17.8-21.4)$ & 42.3 & $(41.2-43.4)$ & $0.000^{1)}$ \\
\hline Yes & 80.4 & $(78.6-82.2)$ & 57.7 & $(56.6-58.8)$ & \\
\hline Utilized healthcare from & & & & & \\
\hline No & 51.1 & $(48.8-53.3)$ & 72.5 & $(71.5-73.5)$ & $0.000^{1)}$ \\
\hline Yes & 48.9 & $(46.7-51.2)$ & 27.5 & $(26.5-28.5)$ & \\
\hline Expenditure quintile & & & & & \\
\hline Poorest & 28.8 & $(26.7-30.8)$ & 17.8 & $(16.9-18.6)$ & $0.000^{2)}$ \\
\hline 2nd & 25.6 & $(23.6-27.5)$ & 18.6 & $(17.7-19.5)$ & \\
\hline $3 r d$ & 18.2 & $(16.5-19.9)$ & 20.5 & $(19.5-21.4)$ & \\
\hline 4 th & 16.2 & $(14.5-17.8)$ & 21.0 & $(20.1-21.9)$ & \\
\hline Richest & 11.3 & $(9.9-12.7)$ & 22.2 & $(21.3-23.1)$ & \\
\hline
\end{tabular}

${ }^{1)}$ Independent sample t-test of proportions ${ }^{2)}$ Chi-square test 
females (28.1\%) in the Mekong region, than in rest of Vietnam (24\%). Households in the Mekong region also had higher proportions of heads above 60 years old and heads of Kinh ethnicity compared to rest of Vietnam. Household heads in the Mekong region also tended to have slightly lower levels of education. Household sizes were similar in both the Mekong Delta and rest of Vietnam, but households in the Mekong region contained a lower proportion of children and a higher proportion of the elderly. Overall urbanization levels were low, with about $76 \%$ and $70 \%$ of households located in rural areas in the Mekong and rest of Vietnam, respectively.

Almost twice as many households in the Mekong Delta region (27\%) reported having experienced an environmental shock in the last 5 years compared to those in other regions (14.4\%). There were also large differences between regions in terms of healthcare utilization. About four-fifths of households in the Mekong Delta region had a household member hospitalized in the past 12 months compared to about a third of households in rest of Vietnam. Households in the Mekong Delta region were also almost twice as likely to have used a private health facility. OOP expenditure on health was closely related to wealth and poverty. The wealth distribution was comparatively poorer in the Mekong Delta region with almost a third of households in the lowest quintile compared to less than a fifth in rest of Vietnam.

\section{Out-of-pocket payments}

Table 2 summarises the average monthly household consumption expenditure, non-food expenditure and OOP healthcare payments in the Mekong Delta region and rest of Vietnam. As can be observed, the average monthly consumption expenditure was higher in the rest of Vietnam (VND 6266 vs. 4900) compared to the Mekong region. Conversely, mean monthly non-food consumption expenditure was slightly higher in the Mekong Delta region (VND 870 vs. 836). Finally, mean OOP healthcare expenditure was higher in the Mekong Delta region.

\section{Catastrophic health expenditure}

Table 3 presents the incidence of CHE by demographic and socio-economic characteristics. The incidence of CHE was higher in the Mekong Delta region compared to rest of Vietnam considering both $10 \%$ of total household expenditure and $40 \%$ of household non-food expenditure as a threshold level. Irrespective of region, households with an elderly head, Kinh ethnicity, and smaller number of members experienced greater $\mathrm{CHE}$ compared to their reference categories. This was also the case for households from rural areas, households that observed economic shock in last 5 years, and households which had no health insurance. These percentages according to background characteristics also tended to be higher in the Mekong Delta region compared to rest of Vietnam particularly when CHE is defined as $10 \%$ of total household expenditure.

\section{Impoverishment effects}

Table 4 shows the economic impoverishment effect of OOP healthcare expenditure in the Mekong Delta and rest of Vietnam. Poverty headcount from OOP healthcare spending was higher in the Mekong Delta region compared to rest of Vietnam. Poverty headcount was also higher in the Mekong Delta region. In 2012, 0.88 million people fell below poverty line $(5.0 \%$ of total population) in the Mekong Delta region for high OOP spending for healthcare.

Table 2 The average monthly household consumption expenditure, non-food expenditure and out of pocket (OOP) healthcare payments in 1000 VND and USD across expenditure quintiles

\begin{tabular}{|c|c|c|c|c|c|c|}
\hline \multirow[t]{3}{*}{ Expenditure } & & \multicolumn{4}{|l|}{ Region } & \multirow[t]{3}{*}{$p$-value* } \\
\hline & & \multicolumn{2}{|c|}{ Mekong Delta region $(N=1905)$} & \multicolumn{2}{|c|}{ Rest of Vietnam $(\mathrm{N}=7494)$} & \\
\hline & & In 1000 VND & In USD & In 1000 VND & In USD & \\
\hline \multirow[t]{3}{*}{ Monthly consumption expenditure } & Mean & 4900.4 & 235.3 & 6266.6 & 300.9 & \multirow[t]{3}{*}{0.000} \\
\hline & Median & 3911.3 & 187.8 & 5222.0 & 250.7 & \\
\hline & SD & 4593.3 & 220.5 & 5037.1 & 241.8 & \\
\hline \multirow[t]{3}{*}{ Monthly non-food expenditure } & Mean & 870.3 & 41.8 & 836.4 & 40.2 & \multirow[t]{3}{*}{0.075} \\
\hline & Median & 710.0 & 34.1 & 645.0 & 31.0 & \\
\hline & SD & 720.2 & 34.6 & 747.4 & 35.9 & \\
\hline \multirow[t]{3}{*}{ Monthly OOP healthcare expenditure } & Mean & 339.5 & 16.3 & 284.4 & 13.7 & \multirow[t]{3}{*}{0.003} \\
\hline & Median & 112.9 & 5.4 & 91.7 & 4.4 & \\
\hline & SD & 876.4 & 42.1 & 685.7 & 32.9 & \\
\hline
\end{tabular}


Table 3 Proportion of population facing catastrophic health expenditure (CHE) in Mekong Delta regions and rest of Vietnam by demographic characteristics

\begin{tabular}{|c|c|c|c|c|c|c|c|c|c|c|}
\hline \multirow[t]{3}{*}{ Characteristics } & \multicolumn{4}{|c|}{$\begin{array}{l}\text { CHE using } 10 \% \text { of total household } \\
\text { expenditure as threshold level }\end{array}$} & \multirow[t]{3}{*}{$P$-value } & \multicolumn{4}{|c|}{$\begin{array}{l}\text { CHE using } 40 \% \text { of household non-food } \\
\text { expenditure as threshold level }\end{array}$} & \multirow[t]{3}{*}{$P$-value } \\
\hline & \multicolumn{2}{|c|}{ Mekong Delta region } & \multicolumn{2}{|c|}{ Rest of Vietnam } & & \multicolumn{2}{|c|}{ Mekong Delta region } & \multicolumn{2}{|c|}{ Rest of Vietnam } & \\
\hline & $\%$ & $95 \% \mathrm{Cl}$ & $\%$ & $95 \% \mathrm{Cl}$ & & $\%$ & $95 \% \mathrm{Cl}$ & $\%$ & $95 \% \mathrm{Cl}$ & \\
\hline \multicolumn{11}{|c|}{ Sex of the household head } \\
\hline Male & 17.3 & $(15.3-19.3)$ & 11.2 & $(10.4-12.0)$ & $0.000^{1)}$ & 25.7 & $(23.4-28.0)$ & 23.3 & $(22.2-24.4)$ & $0.000^{1)}$ \\
\hline Female & 23.2 & $(19.6-26.8)$ & 13.3 & $(11.7-14.9)$ & & 31.8 & $(27.8-35.7)$ & 26.4 & $(24.3-28.4)$ & \\
\hline \multicolumn{11}{|l|}{ Age of household head } \\
\hline Under 60 years & 16.4 & $(14.5-18.3)$ & 9.3 & $(8.5-10.0)$ & $0.000^{1)}$ & 23.3 & $(21.1-25.5)$ & 20.1 & $(19.1-21.2)$ & $0.000^{1)}$ \\
\hline $60+$ & 26.3 & $(22.4-30.1)$ & 20.1 & $(18.1-22.0)$ & & 39.0 & $(34.7-43.3)$ & 37.6 & $(35.3-39.9)$ & \\
\hline \multicolumn{11}{|c|}{ Ethnicity of household head } \\
\hline Kinh & 19.7 & $(17.8-21.5)$ & 13.4 & $(12.6-14.3)$ & $0.000^{1)}$ & 28.3 & $(26.2-30.4)$ & 27.0 & $(25.8-28.1)$ & $0.000^{1)}$ \\
\hline Other & 11.0 & $(6.0-15.9)$ & 4.8 & $(3.7-5.9)$ & & 17.4 & $(11.4-23.4)$ & 12.5 & $(10.9-14.2)$ & \\
\hline \multicolumn{11}{|c|}{ Education of the household head } \\
\hline Upto primary & 20.5 & $(18.4-22.6)$ & 12.3 & $(11.2-13.4)$ & $0.000^{2)}$ & 28.6 & $(26.3-31.0)$ & 23.7 & $(22.3-25.2)$ & $0.004^{2)}$ \\
\hline Secondary & 14.1 & $(10.8-17.5)$ & 11.4 & $(10.3-12.4)$ & & 24.1 & $(20.0-28.3)$ & 25.1 & $(23.7-26.5)$ & \\
\hline University and other & 15.9 & $(6.8-25.0)$ & 9.9 & $(7.3-12.5)$ & & 20.6 & $(10.6-30.7)$ & 18.7 & $(15.3-22.1)$ & \\
\hline \multicolumn{11}{|l|}{ Household size } \\
\hline $1-2$ persons & 24.9 & $(20.2-29.7)$ & 18.7 & $(16.7-20.7)$ & $0.000^{2)}$ & 36.6 & $(31.3-41.9)$ & 36.6 & $(34.2-39.1)$ & $0.000^{2)}$ \\
\hline 3-4 persons & 15.5 & $(13.3-17.8)$ & 10.1 & $(9.1-11.0)$ & & 22.5 & $(19.9-25.1)$ & 20.4 & $(19.1-21.7)$ & \\
\hline 5 persons or more & 21.3 & $(18.1-24.6)$ & 9.7 & $(8.5-11.0)$ & & 30.5 & $(26.9-34.2)$ & 21.9 & $(20.1-23.6)$ & \\
\hline \multicolumn{11}{|c|}{ Having elderly people in the household } \\
\hline No & 15.3 & $(13.3-17.3)$ & 9.3 & $(8.5-10.1)$ & $0.000^{1)}$ & 21.5 & $(19.2-23.8)$ & 19.7 & $(18.6-20.7)$ & $0.000^{1)}$ \\
\hline Yes & 26.0 & $(22.7-29.4)$ & 17.2 & $(15.6-18.7)$ & & 38.8 & $(35.1-42.6)$ & 34.1 & $(32.2-36.1)$ & \\
\hline \multicolumn{11}{|c|}{ Having child in the household } \\
\hline No & 20.6 & $(17.6-23.7)$ & 15.3 & $(14.1-16.6)$ & $0.000^{1)}$ & 30.5 & $(27.0-34.0)$ & 30.4 & $(28.8-32.1)$ & $0.000^{1)}$ \\
\hline Yes & 18.0 & $(15.9-20.2)$ & 9.1 & $(8.2-9.9)$ & & 25.7 & $(23.2-28.1)$ & 19.5 & $(18.3-20.6)$ & \\
\hline $\begin{array}{l}\text { Observed economic/en } \\
\text { shock during past } 5 \text { yea }\end{array}$ & & & 0.0 & & & & & & & \\
\hline No & 15.0 & $(13.1-16.8)$ & 9.9 & $(9.1-10.6)$ & $0.000^{1)}$ & 23.8 & $(21.6-26.1)$ & 22.0 & $(21.0-23.0)$ & $0.000^{1)}$ \\
\hline Yes & 29.7 & $(25.8-33.7)$ & 22.6 & $(20.1-25.1)$ & & 37.1 & $(32.9-41.3)$ & 36.2 & $(33.3-39.0)$ & \\
\hline \multicolumn{11}{|l|}{ Location } \\
\hline Urban & 16.4 & $(13.0-19.9)$ & 11.9 & $(10.5-13.2)$ & $0.354^{1)}$ & 22.8 & $(19.0-26.7)$ & 22.3 & $(20.5-24.0)$ & $0.000^{1)}$ \\
\hline Rural & 19.7 & $(17.7-21.8)$ & 11.6 & $(10.7-12.5)$ & & 28.8 & $(26.5-31.2)$ & 24.8 & $(23.6-26.0)$ & \\
\hline \multicolumn{11}{|c|}{ Household with at least one health insurance enrolee } \\
\hline Yes & 15.1 & $(11.2-18.9)$ & 11.9 & $(9.7-14.2)$ & $0.731^{1)}$ & 21.7 & $(17.2-26.1)$ & 22.9 & $(20.0-25.8)$ & $0.067^{1)}$ \\
\hline No & 19.8 & $(17.8-21.7)$ & 11.7 & $(10.9-12.4)$ & & 28.6 & $(26.4-30.8)$ & 24.2 & $(23.2-25.2)$ & \\
\hline \multicolumn{11}{|l|}{ Hospitalized member } \\
\hline No & 2.4 & $(0.9-4.0)$ & 1.8 & $(1.3-2.3)$ & $0.000^{1)}$ & 4.6 & $(2.4-6.7)$ & 7.3 & $(6.4-8.2)$ & $0.000^{1)}$ \\
\hline Yes & 23.0 & $(20.9-25.1)$ & 18.9 & $(17.8-20.1)$ & & 33.0 & $(30.6-35.3)$ & 36.3 & $(34.9-37.8)$ & \\
\hline \multicolumn{11}{|c|}{ Utilized healthcare from private facility } \\
\hline No & 15.3 & $(13.0-17.6)$ & 10.2 & $(9.4-11.0)$ & $0.000^{1)}$ & 22.8 & $(20.2-25.5)$ & 20.5 & $(19.4-21.6)$ & $0.000^{1)}$ \\
\hline Yes & 22.7 & $(20.1-25.4)$ & 15.7 & $(14.1-17.2)$ & & 32.2 & $(29.2-35.2)$ & 33.4 & $(31.3-35.4)$ & \\
\hline \multicolumn{11}{|l|}{ Expenditure quintile } \\
\hline Poorest & 19.5 & $(16.2-22.8)$ & 13.3 & $(11.5-15.1)$ & $0.000^{2)}$ & 27.0 & $(23.3-30.7)$ & 25.0 & $(22.7-27.3)$ & $0.001^{2)}$ \\
\hline
\end{tabular}


Table 3 Proportion of population facing catastrophic health expenditure (CHE) in Mekong Delta regions and rest of Vietnam by demographic characteristics (Continued)

\begin{tabular}{|c|c|c|c|c|c|c|c|c|c|c|}
\hline \multirow[t]{3}{*}{ Characteristics } & \multicolumn{4}{|c|}{$\begin{array}{l}\text { CHE using } 10 \% \text { of total household } \\
\text { expenditure as threshold level }\end{array}$} & \multirow[t]{3}{*}{$P$-value } & \multicolumn{4}{|c|}{$\begin{array}{l}\text { CHE using } 40 \% \text { of household non-food } \\
\text { expenditure as threshold level }\end{array}$} & \multirow[t]{3}{*}{$P$-value } \\
\hline & \multicolumn{2}{|c|}{ Mekong Delta region } & \multicolumn{2}{|c|}{ Rest of Vietnam } & & \multicolumn{2}{|c|}{ Mekong Delta region } & \multicolumn{2}{|c|}{ Rest of Vietnam } & \\
\hline & $\%$ & $95 \% \mathrm{Cl}$ & $\%$ & $95 \% \mathrm{Cl}$ & & $\%$ & $95 \% \mathrm{Cl}$ & $\%$ & $95 \% \mathrm{Cl}$ & \\
\hline 2nd & 18.7 & $(15.2-22.2)$ & 11.3 & $(9.7-13.0)$ & & 24.6 & $(20.8-28.5)$ & 21.5 & (19.4-23.7) & \\
\hline $3 r d$ & 19.6 & $(15.4-23.8)$ & 9.8 & $(8.4-11.3)$ & & 25.9 & $(21.3-30.6)$ & 22.0 & $(19.9-24.1)$ & \\
\hline 4 th & 19.2 & $(14.8-23.6)$ & 12.0 & $(10.4-13.6)$ & & 32.1 & $(26.9-37.4)$ & 24.4 & $(22.3-26.6)$ & \\
\hline Richest & 16.7 & $(11.7-21.7)$ & 12.1 & $(10.6-13.7)$ & & 30.2 & $(24.1-36.4)$ & 26.9 & $(24.8-29.1)$ & \\
\hline Total & 19.0 & $(17.3-20.8)$ & 11.7 & $(11.0-12.4)$ & 0.000 & 30.2 & $(25.4-29.5)$ & 24.0 & $(23.1-25.0)$ & 0.002 \\
\hline
\end{tabular}

${ }^{1)}$ Independent sample t-test of proportions ${ }^{2)}$ Chi-square test

The impoverishment effect of OOP healthcare payments in the Mekong Delta region vs. rest of Vietnam is presented in Pen's Parade graphs (Fig. 1 a-b). These graphs showed that OOP healthcare payments were largest at higher values in households cumulative proportion of consumption expenditure distribution. However, the households in the middle and lower half of the distribution fell below the poverty line from OOP payments for healthcare in both regions. For households which were already below the poverty line, poverty was further exacerbated for high OOP healthcare payments.

\section{Determinants of CHE and impoverishment}

The inhabitants of the Mekong Delta were 1.766 times more likely to face CHE compared to the rest of Vietnamese using the threshold level $10 \%$ of total household expenditure (Table 5, Model 1). A similar finding (OR = 1.192; 95\% CI: 1.064-1.336) was observed in simple logistic regression using $40 \%$ of household non-food expenditure as the threshold level (Table 5, Model 3). However, these results changed when multiple logistic regression models controlling for background characteristics were used. No significant association between living in the Mekong region and experiencing CHE defined as $10 \%$ of total household expenditure was observed (Table 5, Model 2). When 40\% of houshold non-food expenditure was used as threshold, the direction of the association between living in the Mekong Delta region and experiencing $\mathrm{CHE}$ changed suggesting that Mekong
Delta residents were 0.815 times less likely to face CHE compared to residents of rest of Vietnam (Table 5, Model 4). Among the control variables the significant factors for incidence of CHE, using $10 \%$ of total expenditure as a threshold, were the age of household head, ethnicity, household size, the incidence of any economic or environmental shock in past 5 years, hospitalization, private facility utilization and expenditure quintiles. On the other hand the significant controlling factors for incidence of CHE, using $40 \%$ of non-food expenditure as threshold, were the age of household head, ethnicity, education, household size, having elderly person in household, incidence of any economic or environmental shock in past 5 years, hospitalization, private facility utilization, urban and rural location, and expenditure quintiles.

Living in the Mekong Delta was positively associated with impoverishment from health expenditure. The residents of this region were 1.356 times (95\% CI: 1.005, 1 . 828 ) more likely to face impoverishment from OOP payment for healthcare (Table 6, Model 6). The households from Kinh ethnicity, with greater household size and from a rural location were less likely to face such impoverishment. Households with an older household head were 1.014 times more likely to face impoverishment, while households with a child member were 1.485 times more likely to face impoverishment. Households that faced an economic or an environmental shock in the past 5 years had a higher chance of falling below the

Table 4 Impoverishment from out-of-pocket(OOP) healthcare expenditure in Mekong Delta and rest of Vietnam

\begin{tabular}{lll}
\hline Poverty estimate & $\begin{array}{l}\text { Mekong Delta region } \\
\%(95 \% \mathrm{Cl})\end{array}$ & $\begin{array}{l}\text { Rest of Vietnam } \\
\%(95 \% \mathrm{Cl})\end{array}$ \\
\hline Poverty headcount & $41.1(38.9-43.3)$ & $25.8(24.8-26.8)$ \\
Poverty headcount associated with OOP health expenditure & $5.0(4.0-6.0)$ & $2.3(2.0-2.7)$ \\
Number of individual fell into poverty in association with OOP health expenditure & 875,880 & $1,683,860$ \\
\hline
\end{tabular}

*Two-sample t-test of proportions 
poverty line from a health payment. If household members utilized private facilities, the household was more likely to face impoverishment from healthcare payments.

\section{Discussion}

$\mathrm{CHE}$ and impoverishment from OOP health expenditure is a major challenge to improve health and reducing poverty [10, 12, 18, 20, 22, 28, 29]. Van Doorslaer et al. (2007), using data from VHLSS 2000, found that $15.11 \%$ and $5.97 \%$ of households in Vietnam faced CHE considering $10 \%$ of total health expenditure and $40 \%$ of nonfood expenditure respectively as thresholds [10]. In another multi-country analysis, van Doorslaer et al., (2006) observed that in 11 Asian countries, $2.7 \%$ of the population under study (78 million people) fell below the poverty line due to OOP payments for healthcare [22]. The Mekong Delta region faces particular environmental and health challenges which may impact health expenditure. For example, Nguyen et al. (2017) showed that a high burden of contagious diseases was, at least partially due to environmental and climatic factors in Mekong region [30]. Unlike previous studies, this paper aims at examining the level of OOP healthcare expenditure and CHE and assessing the determinants of health expenditure and impoverishment due to such payments in the Mekong Delta region compared to rest of Vietnam. In order to achieve its first objective, the paper used standard OOP healthcare payments and CHE definitions and measurement; in order to achieve its second objective, the study considered logistic regression models.

The results showed that the level of households' CHE in the Mekong Delta region tended to be higher compared to rest of Vietnam (aggregated data) and that impoverishment effects from health expenditure in the Mekong Delta were stronger. In this region, poverty headcount due to OOP healthcare expenditure was estimated at $5.0 \%$ compared to $2.3 \%$ in rest of Vietnam. Surprisingly, results from the multiple regression models showed either no association or a negative association between living in the Mekong region and CHE.
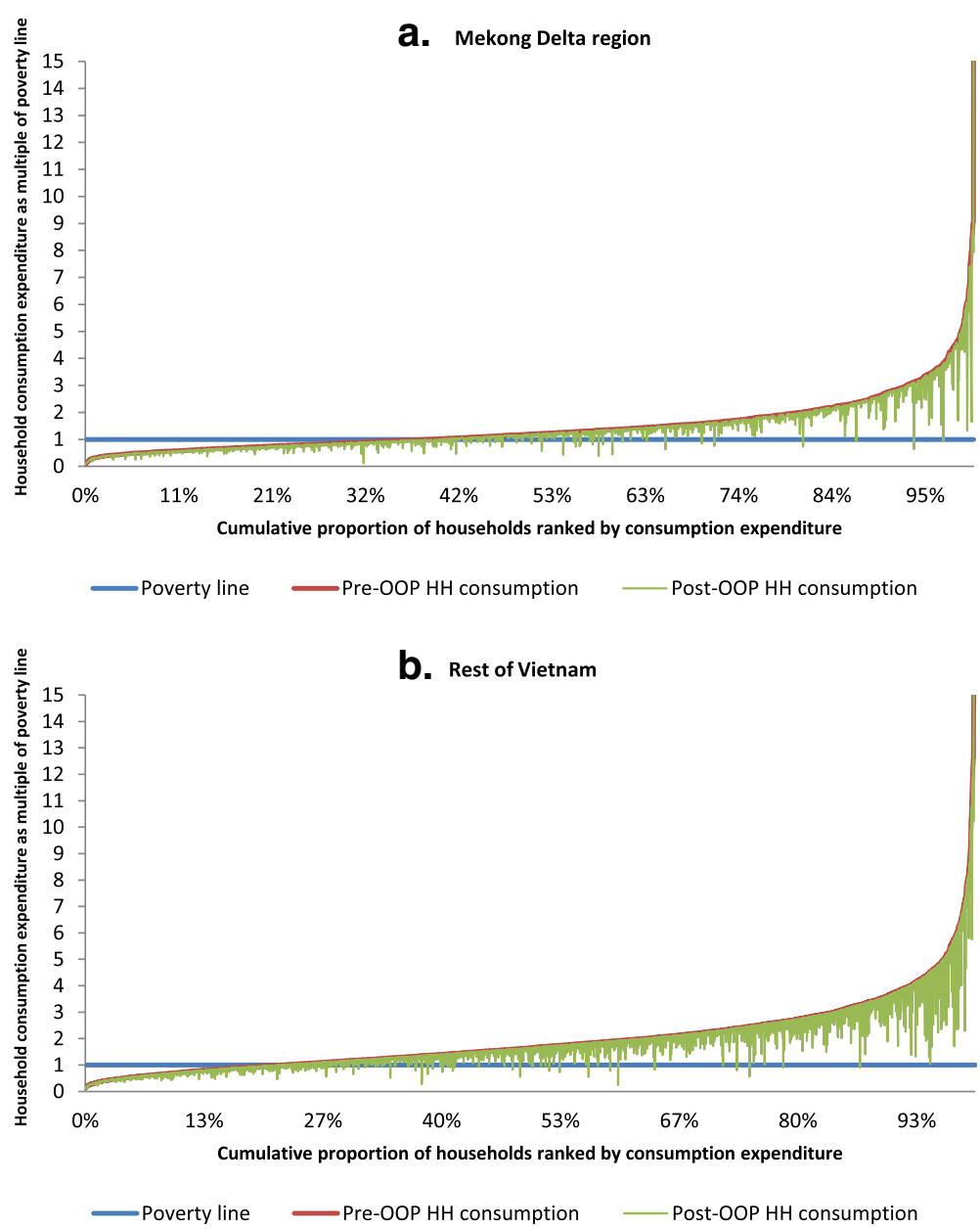

Fig. 1 Effect of out-of-pocket payments on distribution of total household consumption in (a) Mekong Delta regions and (b) Rest of Vietnam 
Table 5 Determinants of catastrophic health expenditure using two threshold levels

\begin{tabular}{|c|c|c|c|c|c|c|c|c|c|}
\hline \multirow[t]{2}{*}{ Variable } & \multirow[t]{2}{*}{ Description } & \multicolumn{2}{|c|}{$\begin{array}{l}\text { Model } 1 \text { (Dependent } \\
=\text { CHE using } 10 \% \text { of } \\
\text { total household } \\
\text { expenditure as } \\
\text { threshold level) }\end{array}$} & \multicolumn{2}{|c|}{$\begin{array}{l}\text { Model } 2 \text { (Dependent } \\
=\text { CHE using } 10 \% \text { of } \\
\text { total household } \\
\text { expenditure as } \\
\text { threshold level) }\end{array}$} & \multicolumn{2}{|c|}{$\begin{array}{l}\text { Model } 3 \text { (Dependent } \\
=\text { CHE using } 40 \% \text { of } \\
\text { household non-food } \\
\text { expenditure as } \\
\text { threshold level) }\end{array}$} & \multicolumn{2}{|c|}{$\begin{array}{l}\text { Model } 4 \text { (Dependent } \\
=\text { CHE using } 40 \% \text { of } \\
\text { household non-food } \\
\text { expenditure as } \\
\text { threshold level) }\end{array}$} \\
\hline & & OR & $95 \% \mathrm{Cl}$ & OR & $95 \% \mathrm{Cl}$ & OR & $95 \% \mathrm{Cl}$ & OR & $95 \% \mathrm{Cl}$ \\
\hline Mekong region & Yes $(\operatorname{Ref}=\mathrm{No})$ & $1.766^{* * *}$ & $(1.544,2.021)$ & 1.154 & $(0.989,1.346)$ & $1.192^{* *}$ & $(1.064,1.336)$ & $0.815^{* * *}$ & $(0.714,0.931)$ \\
\hline $\begin{array}{l}\text { Sex of household } \\
\text { head }\end{array}$ & $\begin{array}{l}\text { Male } \\
(\text { Ref = Female })\end{array}$ & & & 0.96 & $(0.826,1.118)$ & & & 0.94 & $(0.829,1.063)$ \\
\hline $\begin{array}{l}\text { Age of household } \\
\text { head }\end{array}$ & $\begin{array}{l}60+(\text { Ref }=\text { Under } \\
60 \text { years })\end{array}$ & & & $1.014^{* * *}$ & $(1.007,1.021)$ & & & $1.015^{* * *}$ & $(1.009,1.020)$ \\
\hline Ethnicity & Kinh $($ Ref = Other $)$ & & & $0.426^{* * *}$ & $(0.336,0.542)$ & & & $0.517^{* * *}$ & $(0.436,0.613)$ \\
\hline \multirow[t]{2}{*}{$\begin{array}{l}\text { Education of household } \\
\text { head }\end{array}$} & $\begin{array}{l}\text { Secondary (Ref }=U p \\
\text { to primary) }\end{array}$ & & & 1.01 & $(0.870,1.172)$ & & & $1.190^{* *}$ & $(1.057,1.341)$ \\
\hline & $\begin{array}{l}\text { University and other } \\
\text { (Ref = Upto primary) }\end{array}$ & & & 0.97 & $(0.707,1.334)$ & & & 0.85 & $(0.659,1.098)$ \\
\hline \multirow[t]{2}{*}{ Household size } & $\begin{array}{l}3-4 \text { persons } \\
\text { (Ref }=1-2 \text { persons) }\end{array}$ & & & $0.660^{* * *}$ & $(0.539,0.808)$ & & & $0.522^{* * *}$ & $(0.442,0.617)$ \\
\hline & $\begin{array}{l}5 \text { persons or more } \\
\text { (Ref }=1-2 \text { persons) }\end{array}$ & & & $0.619^{* * *}$ & $(0.485,0.790)$ & & & $0.497^{* * *}$ & $(0.408,0.607)$ \\
\hline $\begin{array}{l}\text { Having elderly } \\
\text { people in the household }\end{array}$ & Yes $(\operatorname{Ref}=\mathrm{No})$ & & & 1.09 & $(0.906,1.309)$ & & & $1.235^{* *}$ & $(1.067,1.429)$ \\
\hline $\begin{array}{l}\text { Having child in } \\
\text { the household }\end{array}$ & Yes $(\operatorname{Ref}=\mathrm{No})$ & & & 0.94 & $(0.786,1.115)$ & & & 0.920 & $(0.797,1.052)$ \\
\hline $\begin{array}{l}\text { Observed economic } \\
\text { /environmental } \\
\text { shock during past } 5 \text { years }\end{array}$ & Yes (Ref = No) & & & $2.323^{* * *}$ & $(1.997,2.702)$ & & & $1.900^{* * *}$ & $(1.663,2.171)$ \\
\hline $\begin{array}{l}\text { Household with at least } \\
\text { one health insurance } \\
\text { enrolee }\end{array}$ & Yes $(\operatorname{Ref}=\mathrm{No})$ & & & 1.02 & $(0.826,1.252)$ & & & 1.180 & $(0.995,1.400)$ \\
\hline Hospitalized member & Yes $(\operatorname{Ref}=\mathrm{No})$ & & & $1.238^{* * *}$ & $(1.062,1.442)$ & & & $1.545^{* * *}$ & $(1.363,1.750)$ \\
\hline $\begin{array}{l}\text { At least one member } \\
\text { utilized private facility } \\
\text { in last } 30 \text { days }\end{array}$ & $\operatorname{Yes}(\operatorname{Ref}=\mathrm{No})$ & & & $11.60^{* * *}$ & $(8.944,15.04)$ & & & $6.825^{* * *}$ & $(5.873,7.931)$ \\
\hline Location & Rural (Ref = Urban) & & & 0.95 & $(0.831,1.090)$ & & & 1.102 & $(0.985,1.234)$ \\
\hline \multirow[t]{4}{*}{ Expenditure quintiles } & 2nd (Ref = Poorest) & & & $1.242^{*}$ & $(1.007,1.532)$ & & & $1.199^{*}$ & $(1.006,1.429)$ \\
\hline & 3rd (Ref $=$ Poorest $)$ & & & 1.12 & $(0.894,1.398)$ & & & $1.251^{*}$ & $(1.043,1.501)$ \\
\hline & 4th $($ Ref $=$ Poorest $)$ & & & $1.340^{*}$ & $(1.066,1.686)$ & & & $1.549^{* * *}$ & $(1.284,1.868)$ \\
\hline & $\begin{array}{l}\text { Richest (Ref }= \\
\text { Poorest) }\end{array}$ & & & $1.374^{*}$ & $(1.072,1.760)$ & & & $1.841^{* * *}$ & $(1.507,2.247)$ \\
\hline Constant & & $0.132^{* * *}$ & $(0.123,0.142)$ & $0.008^{* * *}$ & $(0.004,0.014)$ & $0.317^{* * *}$ & $(0.300,0.334)$ & $0.0187^{* * *}$ & $(0.012,0.030)$ \\
\hline N & & 9399 & & 9399 & & 9399 & & 9399 & \\
\hline LR chi2(19) & & -3628 & & -3080 & & -5252 & & -4419 & \\
\hline Prob $>$ chi & & 0.000 & & 0.000 & & 0.003 & & 0.000 & \\
\hline Pseudo R & & 0.009 & & 0.158 & & 0.001 & & 0.159 & \\
\hline
\end{tabular}

Note: ${ }^{*} p<0.05,{ }^{* *} p<0.01,{ }^{* * *} p<0.001$

However, households in the Mekong region were much more likely to be impoverished as a result of healthcare payments compared to households in rest of Vietnam. Impoverishment from health expenditure suggested that health insurance coverage was either poor and/or did not offer sufficient financial protection [31]. Although health insurance coverage in Vietnam is high, it is not universal and this study showed that coverage levels in the Mekong Delta region were about 6.6\% lower compared to the rest of the country. These finding are supported by previous studies, which found that people are paying high OOP for healthcare and facing CHE due to lower coverage of social health insurance for the population in Vietnam $[9,14]$. Nevertheless, expansion of existing insurance models may not be sufficient since our results suggested that health insurance membership did 
not significantly reduce the likelihood of experiencing CHE or provide sufficient protection against impoverishment for OOP healthcare payments. In a recent paper, Kien et al. found that the social health insurance coverage was not effective enough to protect household from the $\mathrm{CHE}$ and impoverishment and he argued that the consumption of prescribed drugs that are not covered by the insurance could be a reason for this [32]. Another study showed that few drugs were prescribed $(40.8 \%)$ by doctors from the essential medicine list, which were covered by social health insurance [33].

Environmental shocks experienced by households had a consistently positive effect on both CHE irrespective of threshold and on impoverishment due to healthcare payments. These findings were in line with existing evidence, which showed a negative effect of environmental shocks beyond direct income loss [34].

Among demographic and socio-economic background characteristics, having a dependent person in the household tended to increase the likelihood of either CHE or OOP healthcare payments related impoverishment. Minh et al. found that households which encountered $\mathrm{CHE}$ and/or were pushed into poverty for high OOP healthcare payments during the period 2002 and 2010 were more common among the households who had more elderly people and those located in rural areas [11]. It was observed that households belonging to lower expenditure quintiles were less likely to face CHE. This might reflect the inability of the poor to divert resources from other basic needs which hinder this population from seeking care when needed and to rely on self-

Table 6 Determinants of impoverishment due to out-of-pocket (OOP) healthcare expenditure

\begin{tabular}{|c|c|c|c|c|c|}
\hline \multirow[t]{2}{*}{ Variable } & \multirow[t]{2}{*}{ Description } & \multicolumn{2}{|c|}{$\begin{array}{l}\text { Model } 5 \text { (Dependent = Poverty } \\
\text { from OOP healthcare payments) }\end{array}$} & \multicolumn{2}{|c|}{$\begin{array}{l}\text { Model } 6 \text { (Dependent = Poverty } \\
\text { from OOP healthcare } \\
\text { payments) }\end{array}$} \\
\hline & & OR & $95 \% \mathrm{Cl}$ & OR & $95 \% \mathrm{Cl}$ \\
\hline Mekong Delta region & Yes $(\operatorname{Ref}=\mathrm{No})$ & $2.182^{* * *}$ & $(1.692,2.816)$ & $1.356^{*}$ & $(1.005,1.828)$ \\
\hline Sex of household head & Male (Ref = Female) & & & 0.738 & $(0.534,1.020)$ \\
\hline Age of household head & $60+($ Ref $=$ Under 60 years $)$ & & & $1.014^{*}$ & $(1.000,1.027)$ \\
\hline Ethnicity of household head & Kinh (Ref = Other) & & & $0.490^{* *}$ & $(0.309,0.775)$ \\
\hline \multirow[t]{2}{*}{ Education of household head } & Secondary (Ref = Upto primary) & & & 1.010 & $(0.750,1.348)$ \\
\hline & University and other (Ref = Upto primary) & & & 0.400 & $(0.121,1.340)$ \\
\hline \multirow[t]{2}{*}{ Household size } & 3-4 persons(Ref $=1-2$ persons) & & & $0.581^{* *}$ & $(0.386,0.875)$ \\
\hline & 5 persons or more(Ref $=1-2$ persons) & & & $0.502^{* *}$ & $(0.305,0.827)$ \\
\hline Having elderly people in the household & Yes $($ Ref $=$ No) & & & 1.170 & $(0.799,1.710)$ \\
\hline Having child in the household & Yes $(\operatorname{Ref}=\mathrm{No})$ & & & $1.485^{*}$ & $(1.005,2.195)$ \\
\hline $\begin{array}{l}\text { Observed economic/environmental } \\
\text { shock during past } 5 \text { years }\end{array}$ & Yes $($ Ref $=$ No) & & & $2.078^{* * *}$ & $(1.548,2.790)$ \\
\hline $\begin{array}{l}\text { Household with at least one health } \\
\text { insurance enrolee }\end{array}$ & Yes $(\operatorname{Ref}=\mathrm{No})$ & & & 1.140 & $(0.741,1.738)$ \\
\hline Hospitalized member & Yes $($ Ref $=$ No) & & & 1.190 & $(0.860,1.650)$ \\
\hline $\begin{array}{l}\text { At least one utilized of private facility } \\
\text { in last } 30 \text { days }\end{array}$ & Yes $($ Ref $=$ No $)$ & & & $5.559^{* * *}$ & $(3.667,8.425)$ \\
\hline Location & Rural (Ref = Urban) & & & 0.810 & $(0.604,1.076)$ \\
\hline \multirow[t]{4}{*}{ Expenditure quintile } & 2nd (Ref = Poorest) & & & $65.32^{* * *}$ & $(20.56,207.6)$ \\
\hline & 3rd (Ref = Poorest) & & & $10.15^{* * *}$ & $(3.098,33.26)$ \\
\hline & 4th (Ref = Poorest $)$ & & & $4.533^{*}$ & $(1.313,15.65)$ \\
\hline & Richest (Ref = Poorest) & & & 1.000 & $(1.000,1.000)$ \\
\hline Constant & & $0.0241^{* * *}$ & $(0.0207,0.0279)$ & $0.0003^{* * *}$ & $(0.000,0.001)$ \\
\hline $\mathrm{N}$ & & 9399 & & 7519 & \\
\hline LR chi2(19) & & -1211.6 & & -864.2 & \\
\hline Prob $>$ chi $^{2}$ & & 0.000 & & 0.000 & \\
\hline Pseudo $R^{2}$ & & 0.013 & & 0.259 & \\
\hline
\end{tabular}

Note: ${ }^{*} p<0.05,{ }^{* *} p<0.01,{ }^{* * *} p<0.001$ 
medication and consequently less OOP healthcare payments $[10,34,35]$. In the current context of increasing public-private mix in service provision in Vietnam, another reason could be the utilization of expensive private facilities by rich people [34, 36]. Minh et al., observed a similar association between expenditure quintiles and CHE in a trend analysis of VHLSS from 2002 to 2010 using multiple regression analysis [11]. Impoverishment related to OOP healthcare payments was higher in 2nd, 3rd' and 4th expenditure quintiles compared to 1st expenditure quintile. This finding was in-line with the Minh et al. [11]. Since people in the 1st expenditure quintile were already living below poverty line, fewer people in this group were at risk of falling below the poverty line due to the OOP healthcare payments. However, this could further exacerbated their poverty condition as shown in Fig. 1. Due to high OOP healthcare payments, the people from 2nd, 3rd and 4th expenditure quintiles were falling below the poverty line as found by another study [11]. However, Kien et al. observed a higher incidence of $\mathrm{CHE}$ and impoverishment among poor groups compared to the rich in a relatively small study (sample size $=492$ slum and 528 non-slum households) in urban Hanoi, Vietnam [32]. A recent study observed that the incidence of impoverishment was decreasing with time in Vietnam [37].

One of the important determinants of CHE and impoverishment was at least one visit to a private facility in the previous thirty days. In Vietnam, private healthcare is paid for either by the patients directly or by their social health insurance or private health insurance scheme [38]. Currently, private health facilities comprise $4.2 \%$ of total hospital beds in Vietnam. Most of these facilities have less than 100 beds and located in cities and towns and offer diverse healthcare services [39]. Earlier studies recommended an increase in the number of private facilities to improve access to healthcare in Vietnam, however, unless sufficiently regulated, this can lead to increased health expenditure and might have adverse impacts on the financial health protection of households [40].

While our study contributed to the existing body of literature, it has several limitations. Use of cross-sectional data was one of the major limitations of this study. Ideally, longitudinal data would be used to estimate the causal effect of impoverishment resulting from OOP payments for healthcare. The multiple regression analysis showed associations between $\mathrm{CHE}$ and impoverishment impact of OOP healthcare expenditure and other factors and these cannot be interpreted as causal relationships. Another limitation was the potential for recall bias, as expenditure data were based on a self-reported questionnaire. Therefore, the estimates in this study should be interpreted taking these into consideration. However, to our knowledge this is the first study in Vietnam, showing the disparities in the impact of high OOP healthcare payments in the environmentally vulnerable Mekong Delta region compared to rest of Vietnam. Another important finding of this study was the association between climate/environmental factors and $\mathrm{CHE}$ and impoverishment.

\section{Conclusion}

This study aimed to investigate the disparities in the prevalence of CHE and OOP healthcare paymentsrelated impoverishment in the Mekong Delta region in comparison with the rest of Vietnam. It also aimed to examine the associations between environmental and economic shocks and households' impoverishments effects. The results of our analysis showed that in the Mekong Delta region, households were significantly more likely to suffer OOP healthcare expenditure related impoverishment. In addition, the analysis showed that households that endured either economic and/or environmental shock during the past 5 years were more likely to suffer from $\mathrm{CHE}$ and impoverishment from OOP healthcare payments.

The results from the multiple regression analysis suggested that in the Mekong Delta region, health insurance did not offer sufficient protection against CHE and impoverishment. Priority should, therefore, be given to increasing financial protection capability of the social health insurance. Additional research should be conducted to identify why health insurance appears not to offer the intended financial protection. The findings of this study also imply that the impacts of environmental and climate change on livelihoods and public health in this region were likely to worsen households' burden of OOP healthcare payments. Strengthening health systems in climate change hotspots, such as the Mekong Delta region, $[36,40]$ will, therefore, be critical. This must involve not only investing in health insurance schemes, in particular for the poorest, but also focus on initiatives to improve reduction and management of natural hazards and disasters. Climate adaptation and policy interventions which lead to a reduction of economic and/or environmental shocks and improve households' coping strategies would be an effective measure to reduce OOP healthcare payments.

\section{Abbreviations \\ CHE: Catastrophic health expenditure; Cl: Confidence interval; GSO: General Statistical Office; OOP: Out-of-pocket; SDG: Sustainable Development Goals; UHC: Universal health coverage; VHLSS: Vietnam household living standards survey; VND: Vietnamese dong}

\section{Acknowledgments}

This work was supported by the Belmont Forum DELTAS project [grant number NE/L008726/1]. icddr,b is thankful to the Governments of

Bangladesh, Canada, Sweden and the UK for providing core/unrestricted support. The authors would like to thank General Statistics Office (GSO) of Vietnam for providing access to the Vietnam Household Living Standard 
Survey 2012 database. We are thankful to Andrew Mirelman of University of York for the language check

\section{Funding}

This work was supported by the Belmont Forum DELTAS project [grant number NE/L008726/1]

\section{Authors' contributions}

SA and SS designed and conceptualized the study and analyzed the secondary data. SA, SS, and KN interpreted the results and drafted the manuscript. All authors contributed to critical revision of the manuscript for important intellectual content, read and approved the final manuscript.

\section{Ethics approval and consent to participate}

This article has been prepared using secondary data from General Statistical Office of Vietnam. Thus, no ethical approval was required for this study.

\section{Competing interests}

The authors declare that they have no competing interests.

\section{Publisher's Note}

Springer Nature remains neutral with regard to jurisdictional claims in published maps and institutional affiliations.

\section{Author details}

${ }^{1}$ Health Economics and Financing Research Group, Health Systems and Population Studies Division, International Centre for Diarrhoeal Disease Research, Bangladesh (icddr,b), 68 Shahid Tajuddin Ahmed Sharani, Mohakhali, Dhaka 1212, Bangladesh. ²Department of Learning, Informatics, Management and Ethics (LIME), Karolinska Institutet, Stockholm, Sweden. ${ }^{3}$ Department of Development and Sustainability, Asian Institute of Technology, Bangkok, Thailand. ${ }^{4}$ Centre for Population Change, University of Southampton, Southampton, UK. ${ }^{5}$ WorldPop, Department of Geography and Environment, University of Southampton, Southampton, UK. ${ }^{6}$ Department of Social Statistics and Demography, University of Southampton, Southampton, UK.

Received: 6 June 2017 Accepted: 3 April 2018

Published online: 27 April 2018

\section{References}

1. Syvitski JPM, Kettner AJ, Overeem I, Hutton EWH, Hannon MT, Brakenridge GR, et al. Sinking deltas due to human activities. Nat. Geosci [internet]. Nat Publ Group; 2009:2:681-686. Available from: https://doi.org/10.1038/ngeo629

2. Foufoula-Georgiou E, Syvitski J, Paola C, Hoanh CT, Tuong P, Vörösmarty C et al. International Year of Deltas 2013: A proposal. Eos, Trans. Am. Geophys. Union [Internet]. 2011; 92: 340-341. Available from: [cited 3 Mar 2017] http://doi.wiley.com/10.1029/2011EO400006

3. Szabo S, Hossain MS, Adger WN, Matthews Z, Ahmed S, Lázár AN, et al. Soil salinity, household wealth and food insecurity in tropical deltas: evidence from south-west coast of Bangladesh. Sustain Sci. 2016;11:411-21. Available from: http://link.springer.com/10.1007/s11625-015-0337-1

4. Szabo S, Renaud F, Hossain S, Sebesvári Z, Matthews Z, Foufoula-Georgiou

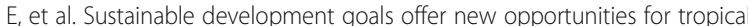
delta regions. Environ. Sci. Policy Sustain Dev. 2015; Available from: http:// eprints.soton.ac.uk/377260/

5. Sherbinin A de, Carr D, Cassels S, Jiang L. Population and Environment. Annu. Rev. Environ. Resour. [Internet]. 2007; 32:345-373. Available from: [cited 3 Mar 2017] http://www.annualreviews.org/doi/10.1146/annurev. energy.32.041306.100243

6. Hummel D, Adamo S, de Sherbinin A, Murphy L, Aggarwal R, Zulu L, et al. Inter- and transdisciplinary approaches to population-environment research for sustainability aims: a review and appraisal. Popul. Environ. [Internet]. 2013; 34:481-509. Springer Netherlands; Available from: [cited 3 Mar 2017] http://link.springer.com/10.1007/s11111-012-0176-2

7. Szabo S, Brondizio E, Renaud FG, Hetrick S, Nicholls RJ, Matthews Z, et al. Population dynamics, delta vulnerability and environmental change: comparison of the Mekong, Ganges-Brahmaputra and Amazon delta regions. Sustain. Sci. [Internet]. 2016;11: 539-554. Springer Japan; Available from: https://doi.org/10.1007/s11625-016-0372-6
8. Few R, Gia Tran P, Thi Thuy Hong B. Living with floods: health risks and coping startegies of the urban poor in Vietnam [Internet]. Norwich; 2004. Available from: www.uea.ac.uk/polopoly_fs/1.19249!studyreportfinal.pdf. Accessed 3 Mar 2017

9. Few R. In: Matthies F, editor. Flood hazards and health: responding to present and future risks. London: Earthscan; 2013.

10. Van Doorslaer E, O'Donnell O, Rannan-Eliya RP, Somanathan A, Adhikari SR, Garg CC, et al. Catastrophic payments for health care in Asia. Health Econ. 2007:16:1159-84.

11. Van Minh H, Kim Phuong NT, Saksena P, James CD, Xu K. Financial burden of household out-of pocket health expenditure in Viet Nam: findings from the National Living Standard Survey 2002-2010. Soc. Sci. Med. [Internet]. 2013: 96:258-263. Available from: [cited 4 June 2014] http://www.ncbi.nlm. nih.gov/pubmed/23246399

12. Chuma J, Maina T. Catastrophic health care spending and impoverishment in Kenya. BMC Health Serv Res. 2012;12:413.

13. UN. Transforming our World: The 2030 Agenda for Sustainable Development [Internet]. New York; 2015. Available from: http://www.un. org/pga/wp-content/uploads/sites/3/2015/08/120815 outcomedocument-of-Summit-for-adoption-of-the-post-2015-developmentagenda.pdf. Accessed 15 Apr 2017.

14. Somanathan A, Tandon A, Lan Dao H, Hurt KL, Fuenzalida-Puelma HL. Moving towards universal health coverage of social health Insurance in Vietnam. Washington DC: The World Bank; 2014.

15. Tuan PL. Vietnam 2013 general health accounts and disease expenditures with sub-analysis of 2013 HIV/AIDS expenditure. Hanoi. USAID \& HFG; 2016.

16. Coxhead I, Vu L, Nguyen C. Migration in Vietnam: new evidence from recent surveys. Munich. Munich Personal RePEc Archive; 2016.

17. Hansen $H$, Le TD. The importance of being surveyed: the representativeness and impact of the Vietnam household living standards surveys. Copenhagen. University of Copenhagen; 2013

18. Wagstaff A, van Doorslaer E. Catastrophe and impoverishment in paying for health care: with applications to Vietnam 1993-1998. Health Econ. 2003:12:921-34

19. Wagstaff A. Measuring financial protection in health. Policy Res Work Pap. 2008:1-31.

20. Xu K, Evans DB, Kawabata K, Zeramdini R, Klavus J, Murray CJL. Household catastrophic health expenditure: a multicountry analysis. Lancet. 2003;362:111-7.

21. Sekher TV, Kumar K. Catastrophic Health Expenditure and Poor in India : New Evidence from a Nation-wide Survey. IUSSP Conf. [Internet]. 2012:1-10. Available from: http://paa2012.princeton.edu/papers/121467. Accessed 1 Apr 2017

22. Van Doorslaer E, O'Donnell O, Rannan-Eliya RP, Somanathan A, Adhikari SR, Garg CC, et al. Effect of payments for health care on poverty estimates in 11 countries in Asia: an analysis of household survey data. Lancet. 2006:368:1357-64.

23. The State Bank of Vietnam. Annual Report 2012. Hanoi. The State Bank of Vietnam; 2012.

24. Xu K. Distribution of health payments and catastrophic expenditures methodology [internet]. Geneva: FER/EIP Discuss. Pap; 2005. Available from: http://www.who.int/health_financing/documents/dp_e_05_2-distribution_ of health payments.pdf. Accessed 13 Sep 2015.

25. World Bank. Well Begun, Not Yet Done: Vietnam's remarkable progress on poverty reduction and the emerging challenges. Washington DC: Vietnam poverty assess; 2012. p. 2012

26. GSO. Result of the Vietnam's household living standards survey 2010. Hanoi. General Statistical Office; 2010.

27. GSO. Poverty and migration profile [Internet]. Hanoi; 2012. Available from: https://www.gso.gov.vn/Modules/Doc_Download.aspx?DocID=16773

28. Tomini SM, Packard TG, Tomini F. Catastrophic and impoverishing effects of out-of-pocket payments for health care in Albania: evidence from Albania living standards measurement surveys 2002, 2005 and 2008. Health Policy Plan. 2012:28:419-28.

29. Amaya Lara JL, Ruiz Gómez F. Determining factors of catastrophic health spending in Bogota, Colombia. Int J Health Care Finance Econ. 2011;11:83-100

30. Nguyen HX, Chu C, Nguyen HLT, Nguyen HT, Do CM, Rutherford S, et al. Temporal and spatial analysis of hand, foot, and mouth disease in relation to climate factors: A study in the Mekong Delta region, Vietnam. Sci. Tota Environ. 2017;581-582:766-772.

31. WHO. The world health report: health systems financing: the path to universal coverage. Geneva. Geneva: World Health Organisation; 2010. 
32. Kien VD, Van Minh H, Giang KB, Dao A, Tuan LT, Ng N, et al. Socioeconomic inequalities in catastrophic health expenditure and impoverishment associated with non-communicable diseases in urban Hanoi, Vietnam. Int J Equity Health. 2016;15:169. Available from: http://equityhealthj.

biomedcentral.com/articles/10.1186/s12939-016-0460-3

33. Ministry of Health of Viet Nam. Health Partnership group. Join annual health review. Towards universal health coverage. Hanoi. 2013:2013.

34. Ekman B, Liem NT, Duc HA, Axelson H. Health insurance reform in Vietnam: a review of recent developments and future challenges. Health Policy Plan. 2008;23:252-63.

35. World Bank. Vietnam - aiming high: Vietnam development report 2007. Washington DC; 2006.

36. Ha NTH, Berman P, Larsen U. Household utilization and expenditure on private and public health services in Vietnam. Health Policy Plan [Internet]. 2002;17:61-70. Available from: http://heapol.oxfordjournals.org/content/17/ 1/61.abstract

37. Wagstaff A, Flores G, Smitz M-F, Hsu J, Chepynoga K, Eozenou P. Progress on impoverishing health spending in 122 countries: a retrospective observational study. Lancet Glob Heal. 2017;6(2):e180-e192.

38. Nguyen MP, Wilson A. How could private healthcare better contribute to healthcare coverage in Vietnam? Int J Heal Policy Manag [Internet]. 2017;6: 305-8. Available from: http://ijhpm.com/article_3312.html

39. GSO. Vietnam's Health activities through the 2012 Etablishment census. Hanoi. General Statistical Office; 2014.

40. Duc HA, Sabin LL, Cuong LQ, Thien DD, Feeley R. Potential collaboration with the private sector for the provision of ambulatory care in the Mekong region. Vietnam Glob Health Action. 2012;5:1-11.

Ready to submit your research? Choose BMC and benefit from:

- fast, convenient online submission

- thorough peer review by experienced researchers in your field

- rapid publication on acceptance

- support for research data, including large and complex data types

- gold Open Access which fosters wider collaboration and increased citations

- maximum visibility for your research: over $100 \mathrm{M}$ website views per year

At BMC, research is always in progress.

Learn more biomedcentral.com/submissions 